\title{
Land-Use Planning for Nearshore Ecosystem Services- The Puget Sound Ecosystem Portfolio Model
}

he 2,500 miles of shoreline and
nearshore areas of Puget Sound,
Washington, provide multiple benefits
to people_"ecosystem services"-_
including important fishing, shellfishing,
and recreation industries. To help resource
managers plan for expected growth in
coming decades, the U.S. Geological
Survey Western Geographic Science
Center has developed the Puget Sound
Ecosystem Portfolio Model (PSEPM).
Scenarios of urban growth and shoreline
modifications serve as model inputs to
develop alternative futures of important
nearshore features such as water quality
and beach habitats. Model results will
support regional long-term planning
decisions for the Puget Sound region.

The Puget Sound region of northwestern Washington, home to more than 4 million people, comprises a major U.S. estuary with many rivers and streams draining an area of more than 13,000 square miles. The complicated bays and waterways of the sound have 2,500 miles of shoreline - bluffs, beaches, mudflats, kelp and eelgrass (Zostera marina) beds, salt marshes, gravel spits, and estuaries. This highly productive zone supports valuable fishing, shellfishing, and recreation industries, which contribute billions of dollars to the State's economy. The food, water, cultural, and recreational benefits people obtain from nearshore environments are considered "nearshore ecosystem services."

The Puget Sound region continues to experience rapid development and growth in population, which is expected to reach 5.4 million residents by 2025 . This future growth can affect nearshore ecosystem services by increasing water pollution and nutrient loading and by modifying coastal habitats. The land-use decisions made to accommodate this growth will influence whether Puget Sound environments are further degraded, maintained, or successfully restored. Resource managers need tools to identify where and why potential impacts to ecosystem services may occur to plan for ensuring their long-term sustainability.

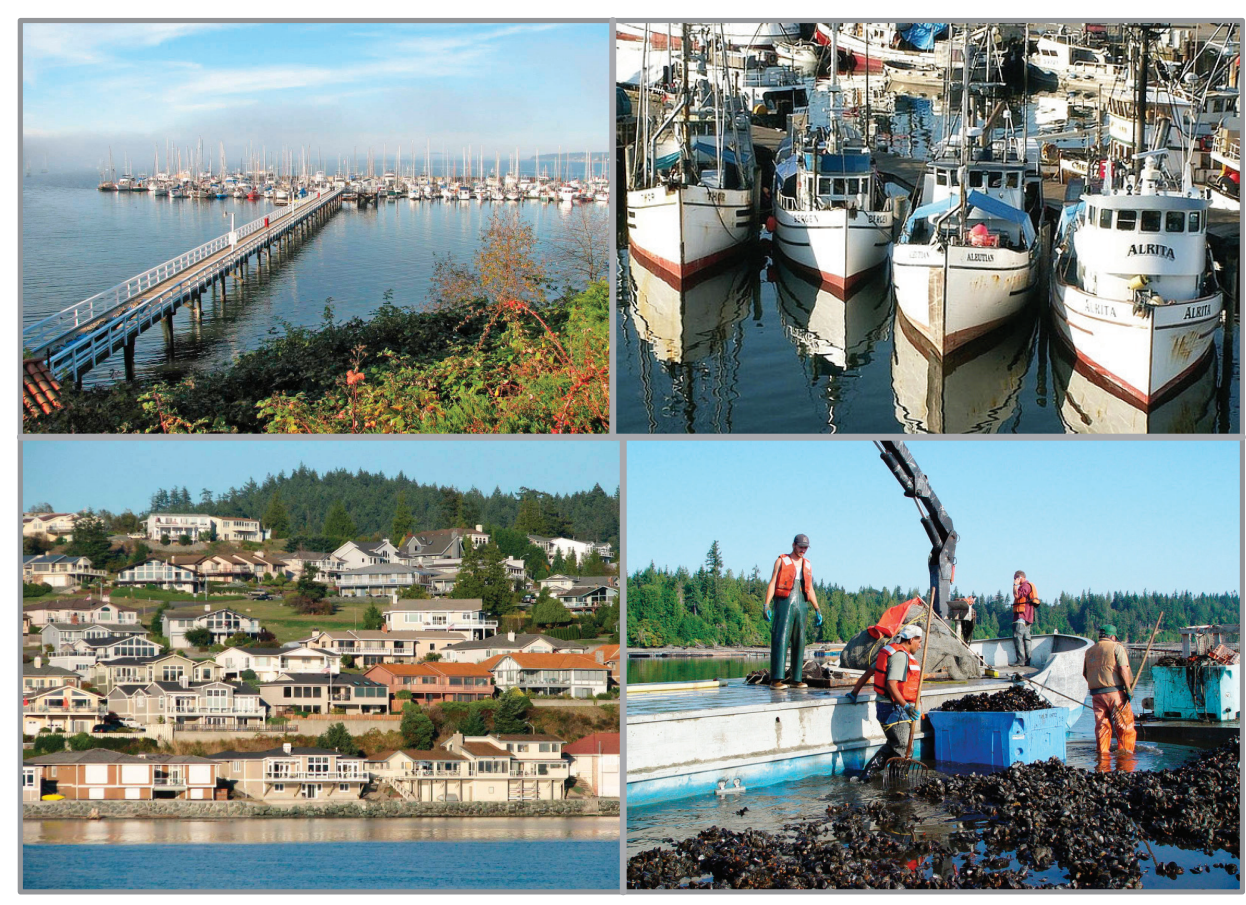

The many benefits to people (ecosystem services) of the Puget Sound, Washington, nearshore are illustrated by (clockwise from upper left) recreational boating at Port Hadlock marina (photo (c) Hugh Shipman); fishing (photo (C) JPaul Grow); mussel harvesting (photo (C) Jon Rowley); and waterfront living in Anacortes (photo (C) Hugh Shipman). The Puget Sound Ecosystem Portfolio Model will provide planners data needed to accommodate expected growth and development while preserving and protecting these ecosystem services.

Although it is not known where and how much development will occur in the future, the influences of population growth, regulations, and public preference can be

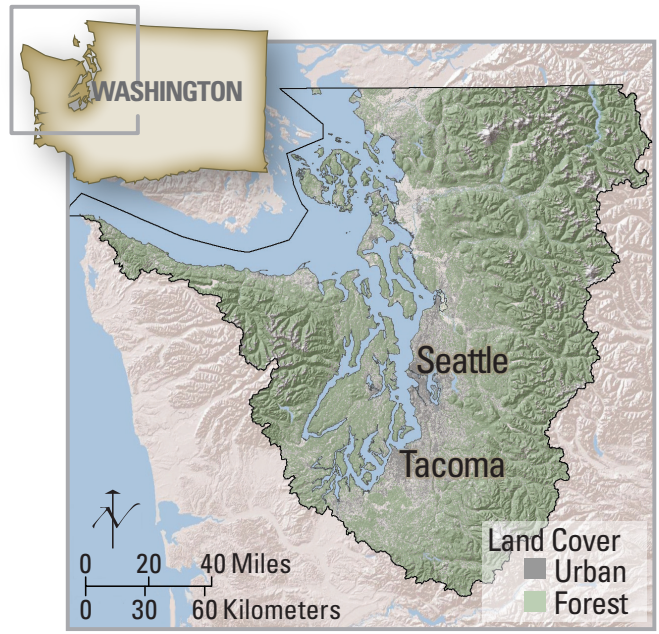

The Puget Sound, Washington, region (watershed outlined here) includes intricate waterways that stretch along 2,500 miles of shoreline and adjacent nearshore waters. monitored. Instead of trying to predict development patterns, planners can develop scenarios, which may include maps that show, for example, where people might live and work in 2060. Scientists can then determine how the nearshore ecosystems may change under each scenario.

\section{The Puget Sound Ecosystem Portfolio Model}

The U.S. Geological Survey (USGS) Western Geographic Science Center (WGSC) has been working with the U.S. Environmental Protection Agency, shoreline planners, public health officials, and others to develop the Puget Sound Ecosystem Portfolio Model (PSEPM). Based on earlier efforts (http://pubs.usgs.gov/sir/2009/5181/), the PSEPM is a decision support tool that uses scenarios to evaluate where, when, and to what extent future population growth, urban development, and shoreline development may alter the nearshore environment 
Puget Sound Ecosystem Portfolio Model Subcomponents

\begin{tabular}{|c|c|c|c|}
\hline 「 Scenarios of urban gro & th/population distribution/shorel & e modification - & $\begin{array}{l}\text { change (purple boxes). Submodel } \\
\text { outputs are used to assess future }\end{array}$ \\
\hline $\begin{array}{l}\text { Shellfish Pollution Model } \\
\text { Uses scenarios of land-cover change to estimate } \\
\text { fecal coliform bacteria concentrations in } \\
\text { commercial shellfish growing areas, given } \\
\text { expected development patterns in watersheds } \\
\text { draining to the nearshore. }\end{array}$ & $\begin{array}{l}\text { Recreation Visits Model } \\
\text { Uses scenarios of population } \\
\text { distributions in Puget Sound to } \\
\text { model changes in State Park beach } \\
\text { visitation and stresses on } \\
\text { recreational resources. }\end{array}$ & $\begin{array}{l}\text { Beach Armoring Index } \\
\text { Uses scenarios of shoreline } \\
\text { modification to rank beaches based } \\
\text { on the potential for physical and } \\
\text { ecological changes due to cumulative } \\
\text { onsite and updrift armoring. }\end{array}$ & $\begin{array}{l}\text { changes to ecosystem services (blue } \\
\text { boxes). The submodel results may } \\
\text { provide information about more than } \\
\text { one ecosystem service. For example, } \\
\text { Beach Armoring Index results affect } \\
\text { the spawning potential of forage fish }\end{array}$ \\
\hline $\begin{array}{l}\text { Commercial/Tribal } \\
\text { shellfish habitat suitability }\end{array}$ & $\begin{array}{l}\text { Recreational be } \\
\text { quality }\end{array}$ & $\begin{array}{l}\text { Forage-fish spawning } \\
\text { potential }\end{array}$ & $\begin{array}{l}\text { is also affected by Recreational Visits } \\
\text { Model results. }\end{array}$ \\
\hline
\end{tabular}

50 years from now. The tool focuses on impacts to barrier beaches and bluff-backed beaches, which represent $50 \%$ of Puget Sound shorelines by length.

The PSEPM presents three possible futures of the nearshore by analyzing three growth scenarios developed out to 2060:

- Status Quo_continuation of current trends.

- Managed Growth - adoption of an aggressive set of land-use management policies.

- Unconstrained Growth - relaxation of land-use restrictions.

These scenarios were developed by scientists at Oregon State University and provide information on projected population, land cover, and, in coastal areas, shoreline modifications (see http:// envision.bioe.orst.edu/StudyAreas/ PugetSound/index.html). PSEPM model outputs include maps that identify shoreline sections where nearshore resources may be more strongly affected by changes on the land.

\section{Model Subcomponents and Results}

The PSEPM comprises three submodelsthe Shellfish Pollution Model, the Recreation Visits Model, and the Beach Armoring Index - that identify connections between changes on the land and the capacity of the nearshore to support ecosystem services. Results from the PSEPM identify where and when future changes to nearshore ecosystems and ecosystem services will likely occur within the three urban growth scenarios. The model results will improve understanding of potential changes in nearshore ecosystem services by:

- Highlighting resource-rich areas that may potentially be affected by multiple stressors;

- Helping to prioritize sites for further study and higher level conservation and restoration planning;

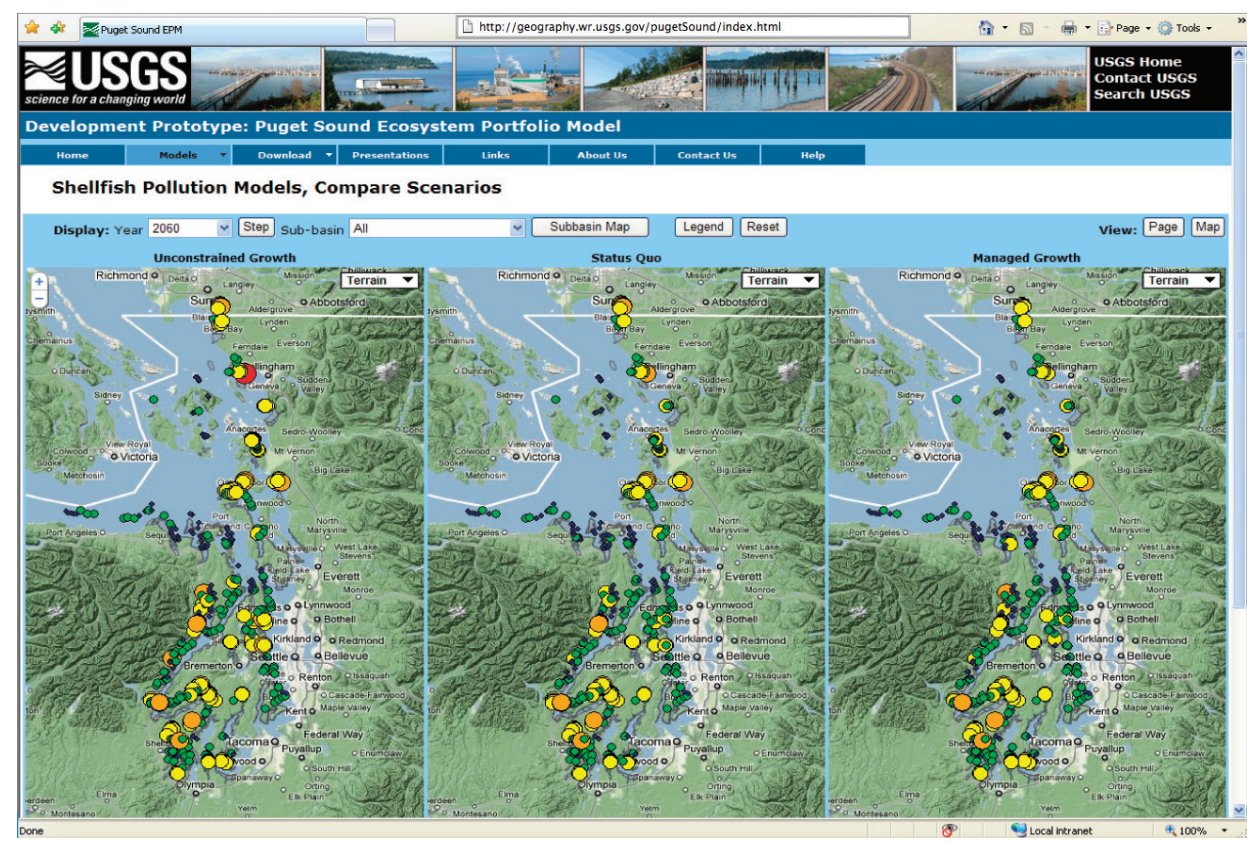

Users of the PSEPM Web site (http://geography.wr.usgs.gov/pugetSound/index.html) can view model results and compare scenarios using a Web-based mapping application. A three-map viewer allows the user to view, compare, and contrast results at the data-point scale or at the regional scale across three scenarios simultaneously. Model results can also be downloaded on a data download page.

- Providing planners with the ability to focus on targeted areas in order to meet regional land-use planning goals; and

- Providing the foundation for evaluating changes in Puget Sound ecosystem services within integrated scenarios of climate change and land-use change.

The work of Western Geographic Science Center (WGSC) scientists in developing the Puget Sound Ecosystem Portfolio Model is only part of WGSC's efforts to better understand the causes and consequences of land-cover change. WGSC is continuing productive collaborations with public land managers, tribal leaders, and local communities to help ensure that they have the crucial information they need to make informed decisions about ongoing and future landuse choices.

\section{Kristin Byrd}

Edited by Peter H. Stauffer

Graphics and layout by Jeanne S. DiLeo

COOPERATING ORGANIZATIONS

U.S. Environmental Protection Agency

Oregon State University

Washington State Department of Ecology

Washington State Department of Health

Washington State Parks and Recreation Commission

Natural Capital Project, Stanford University

\section{For more information contact: Kristin Byrd \\ U.S. Geological Survey \\ 345 Middlefield Road, MS 532 \\ Menlo Park, CA 94025 \\ Tel. (650) 329-4279 \\ kbyrd@usgs.gov}

http://geography.wr.usgs.gov/ http://geography.wr.usgs.gov/pugetSound/index.htm

This Fact Sheet and any updates to it are available online at http://pubs.usgs.gov/fs/2011/3067/ 